\title{
微粒シラスバルーンの特性
}

\author{
袖山研一・目 義雄 ${ }^{*} \cdot$ 神野好孝・浜石和人 \\ 鹿児島県工業技術センター素材開発部，899-51 鹿児島県姶良郡隼人町小田 1445-1 \\ *金属材料技術研究所反応制御研究部，305 つくば市千現 1-2-1
}

\section{Properties of Fine Shirasuballoons}

\author{
Kenichi SODEYAMA, Yoshio SAKKA*, Yoshitaka KAMINO and Kazuto HAMAISHI \\ Materials Division, Kagoshima Prefectural Institute of Industrial Technology, 1445-1, Oda, Hayato-cho, Aira-gun, Kagoshima 899-51 \\ *Chemical Processing Division, National Research Institute for Metals, 1-2-1, Sengen, Tsukuba-shi, Ibaraki 305
}

\begin{abstract}
Hollow glass microspheres named Shirasuballoons have been produced from glassy volcanic fragment named as Shirasu or Hakudo. Finer Shirasuballoons are required to increase in physical and chemical properties of conventional Shirasuballoons and glass balloons. Fine Shirasuballoons of mean particle sizes under $20 \mu \mathrm{m}$ and bulk densities under $0.5\left(10^{3} \mathrm{~kg} / \mathrm{m}^{3}\right)$ were successfully prepared by rapid heating of milled powders using a fluidized bed furnace. Strengths, thermal stabilities and chemical durabilities of fine Shirasuballoons, conventional Shirasuballoons and glass balloons were measured under the same conditions. Strengths and chemical durabilities of fine and conventional Shirasuballoons were obviously superier to these of conventional glass balloons. Higher the particle density of fine Shirasuballoons tended to increase in the strength. Fine and conventional Shirasuballoons held their structure up to $800^{\circ} \mathrm{C}$, approximately $200^{\circ} \mathrm{C}$ higher than the conventional glass balloons.

[Received June 3, 1996; Accepted September 19, 1996]
\end{abstract}

Key-words : Hollow glass microsphere, Microballoon, Shirasuballoons, Bulk density, Whiteness, Strength, Thermal stability, Chemical durability

\section{1. 緒 言}

軽量フィラーのなかでバルーンと呼ばれる微小中空球は，軽 量・断熱性という優れた機能を持ち，等方性でめるため，マト リックス材料に異方性を与えず，耐衝撃性を付与できる。成形 加工時には, 粘性抵抗を小さくし, 流動性やハンドリング性に 優れ，成形体の寸法安定性や切削加工性に優れるなどの特徵を もつ (1),2)。バルーンの用途は, 海洋浮力材, 耐圧軽量部材, 塗 料・パテ増量材, 白色顔料代用, 工業用爆薬, 反応塔充填材, セメント系建築材料, 紙粘土, 熱硬化性・熱可塑性樹脂などで あり，有機質よりもシラスバルーンやガラスバルーンなどの無 機質のものが多く使用さ机る11,3)

シラスバルーンは，シラ久などのガラ久質火山砕屑物を焼成 発泡させたもので，主成分はアルミノケイ酸塩ガラ久からな る、シラ久バルーンはガラ久バルーンと比較して低価格であ り，九州工業技術研究所で開発されて以来4)，1992年に国内で 約 1 万 2 千トン/年生産されるまでになっている5).

これらバルーンは，せん断力に対して弱いため，樹脂やセメ ントなどと混合したときに壊れやすいという久点がある。この 解決策上して微細化による高強度化がある西。この微細化によ り樹脂, 特殊塗料, 特殊接着剂, 洗剂, 化粧品, 金属複合材な ぞ付加価值の高い新用途への展開が期待できる.

これまで九州工業技術研究所の水熱反応による風化表面層形 成による方式7) と著者らのグループの急速加熱の方法8),9)によ り平均粒径 $20 \mu \mathrm{m}$ 以下, 加密度 $0.5\left(10^{3} \mathrm{~kg} / \mathrm{m}^{3}\right)$ 以下の微粒 シラスバルーンの開発に成功している。しかしながら, 微粒シ ラスバルーンの特性に関するデータはほとんど公表されていな (3).

今回は，微粒シラ久バルーン及び市販のシラスバルーンとガ ラスバルーンの物性を同一の条件で比較した。その結果，微粒 シラスバルーンが市販のシラスバルーン，ガラスバルーンより も強度に優れ，市販のガラ久バルーンよりも耐熱性と化学的耐 久性に優れることが分かったので報告する。

\section{2. 実験方法}

微粒シラ久バルーンは，加久藤シラ久 (清新産業製)，吉田 シラ久 (柏原産業製)，中野白土（丸中白土製），美英白土（美 瑛白土工業製）のガラ久質火山砕屑物を衝突板式 JET 気流粉 砕分級装置（日本ニューマチック工業製，IDS-2型）によって 粉砕後, 北開試式砂媒体流動床炉を用いて急速加熱法により発

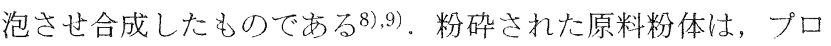
パンガスと空気の混合ガスとともに炉の下部から供給し，直径 $1 \mathrm{~mm}$ 程度のアイ砂により高温で流動化している流動床部分で 1s 以下で高温まで加熱される。そこで発泡した後, 燃焼ガ火 とともに流動床から放出され，冷却されながらサイクロン又は バグフィルターに送られ，連続的に捕集される。最高加熱温度 は950 $1100^{\circ} \mathrm{C}$, 原料処理量約 $1 \mathrm{~kg} / 1 \mathrm{~h} て ゙$, 生ガ久流速と温度 分布から求めた最高温度到達時間は， $0.05 \sim 0.06 \mathrm{~s}$ 以下であっ た9)。

市販のシラスバルーンは，イヂチ化成製ウィンライトを16 種類, シラックスウ製 SILAX を 9 種類, 釧路石炭乾溜製シリ

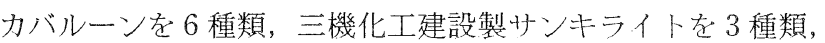
美瑛白土工業製タイセツバルーンを 4 種類，大建工業製 DSRF 1 種類, 昭和化学工業製久ーパーバルーンを 2 種類 用いた。これらは，ガラ火質火山砕屑物を選鉣選別し粒度調整 後, 主に媒体流動床炉により $1000^{\circ} \mathrm{C}$ 前後で焼成して製造され ている. その特長は, 低かさ比重, 不燃性, 高融点, 低熱伝導 率, 低誘電率, 無色, 無害, 有毒ガ久の発生がない, 低洒格な どである10)。

市販のガラスバルーンは，東海工業製 CEL-STAR を24種 類（販売：旭硝子），米国 PQ 社製 Q-CEL t2 種類（販売： 旭硝子)，米国久リーエム社製久コッチライトグラ久バブル久 を 5 種類（販売：住友入リーエム），東芝バロティ一二製，東 芝中空ガラスビーズを1種類，米国W. R. Grace 社製 GLASS MICROBALLOON を1 種類 (販売 : 日本シリカ工業) を用いた。通常のガラスバルーンは，ガラ久粉末を火炎中に投 
入噴霧してつくられて抢り, 種類も多く, 化学組成, 製造方法 もそれぞれ異なる11,2).

粉体特性としては, 粒度分析, かさ密度, 白色度, 粒子密 度, 強度 (体積減少率), 耐熱性, 耐化学薬品性の測定を行っ た.シラスバルーンの粉体特性の測定法は, 火山ケイ酸塩工業 (VSI) 研究会規格（案）11)があるが，JISでの規定がない。 また，微粒シラスバルーンは，非常に微細な粉体であり，既存 の測定法では評価が困難な場合がある。そこで，今回は，同一 の条件でこれらの物性を評価するために, 下記の測定方法で 行った。

粒度分析は, $875 \mu \mathrm{m}$ 以下の粒子から成る試料については, レーザー回折式粒度分析装置 (Sympatec 社製, HELOS-RODOS, 販壳：日本レーザー）を用い，付属の気流分散装置又 は水中分散装置を用いて乾式分散又は湿式分散して平均粒径を 測定した． $875 \mu \mathrm{m}$ 以上の粒子を含む試料については，JIS 子 るいにより分粒し，子るい下累積分布から平均粒径を求めた。

かさ密度は, ホソカワミクロン製パウダーテスター PT-E 型と，付属の金属製カップ（内容積 $100 \mathrm{~cm}^{3}$ ) を用いて，タッ プ高さ $20 \mathrm{~mm}$, タップ速度 60 回 $/ \mathrm{min}$, タップ回数 200 回の条件 で測定した。このかさ密度は，VSI 研究会の測定法に準じ た ${ }^{11)}$.

粒子密度は, 湯浅アイオニクス製マルチピクノメーター MVP-1 型を用い, He ガ久置換法により求めた供試体の体積 とその重量から算出した。

白色度は, 測色色差計（スガ試験機製，SM-4-2 型）を用 いて測定し，次式により白色度 $(W)$ を算出した ${ }^{12)}$ 。

$$
W=100-\left\{(100-L)^{2}+a^{2}+b^{2}\right\}^{1 / 2}
$$

ここで, $L$ はハンターの色差式における明度指数, $a, b$ は色座 標である。

強度試験については，VSI 研究会の静水圧浮揚率の測定法
によると, 呼び寸法 $32 \mu \mathrm{m}$ の網子るいを用いて水中で試料を 固定し, $8 \mathrm{MPa}$ で $60 \mathrm{~s}$ 以上加圧後, 水浮揚物上水沈降物を分 離, 秤量して静水圧浮揚率を算出しているが11), 微粒シラス バルーンの場合は, このふるいを通過してしまうので, 本実験 では約 $100 \mathrm{~g}$ の試料をゴム袋にエタノールで分散して充填する 方法（静水圧法と略す）及び乾式粉末充填する方法（乾式充填 法）を用い，密封後，日機装製冷間等方圧プレス CL4-22-60 型を用いて10 MPa で10 min 保持し, その加圧前後の粒子密 度から算出した体積減少率で強度を評価した。

耐熱性試験は, 約 $100 \mathrm{~g}$ の試料をアドバンテック東洋製超高 速昇温電気炉 $\mathrm{KSH}-2$ 型により $15^{\circ} \mathrm{C} / 60 \mathrm{~s}$ で昇温し, 500 $900^{\circ} \mathrm{C}$ 温度範囲で大気中 $2 \mathrm{~h}$ 保持後自然放冷した。 その加熱 前後の白色度とかさ密度を測定し耐熱性を評価した. 更に加熱 前後の試料表面を走査型電子顕微鏡(SEM; 日本電子製,

JSM-840）により観察した.

耐化学薬品性については, 塩酸又は水酸化ナトリウムで調整 した $\mathrm{pH}$ 1 $\mathrm{pH} 13$ の水溶液 $40 \mathrm{~cm}^{3}$ に試料 $2.5 \mathrm{~g}$ を $48 \mathrm{~h}$ 浸せき 後, 沪過洗浄し, $100^{\circ} \mathrm{C}, 20 \mathrm{~h}$ 乾燥後秤量して重量減少率を求 めた.

\section{3. 結果と考察}

表 1 は, 当所で合成した微粒シラスバルーンと市販のシラス バルーン 40 種類及び市販のガラスバルーン 33 種類の平均粒径 とかさ密度の測定結果を製品別にまとめて示した。

表 2 は, 強度試験, 耐熱性試験, 耐化学薬品性試験に用いた 微粒シラスバルーン 11 種類, 市販のシラスバルーン 2 種類, 市販のガラスバルーン 2 種類の平均粒径, かさ密度, 粒子密 度の測定結果を示した. 図 1 に全試料の平均粒径とかさ密度の 関係を示した。図中のサンプル記号は表 1 及び表 2 と対応し ている。

Table 1. Physical Properties of Fine Shirasuballoons, Conventional Shirasuballoons and Conventional Glass Balloons

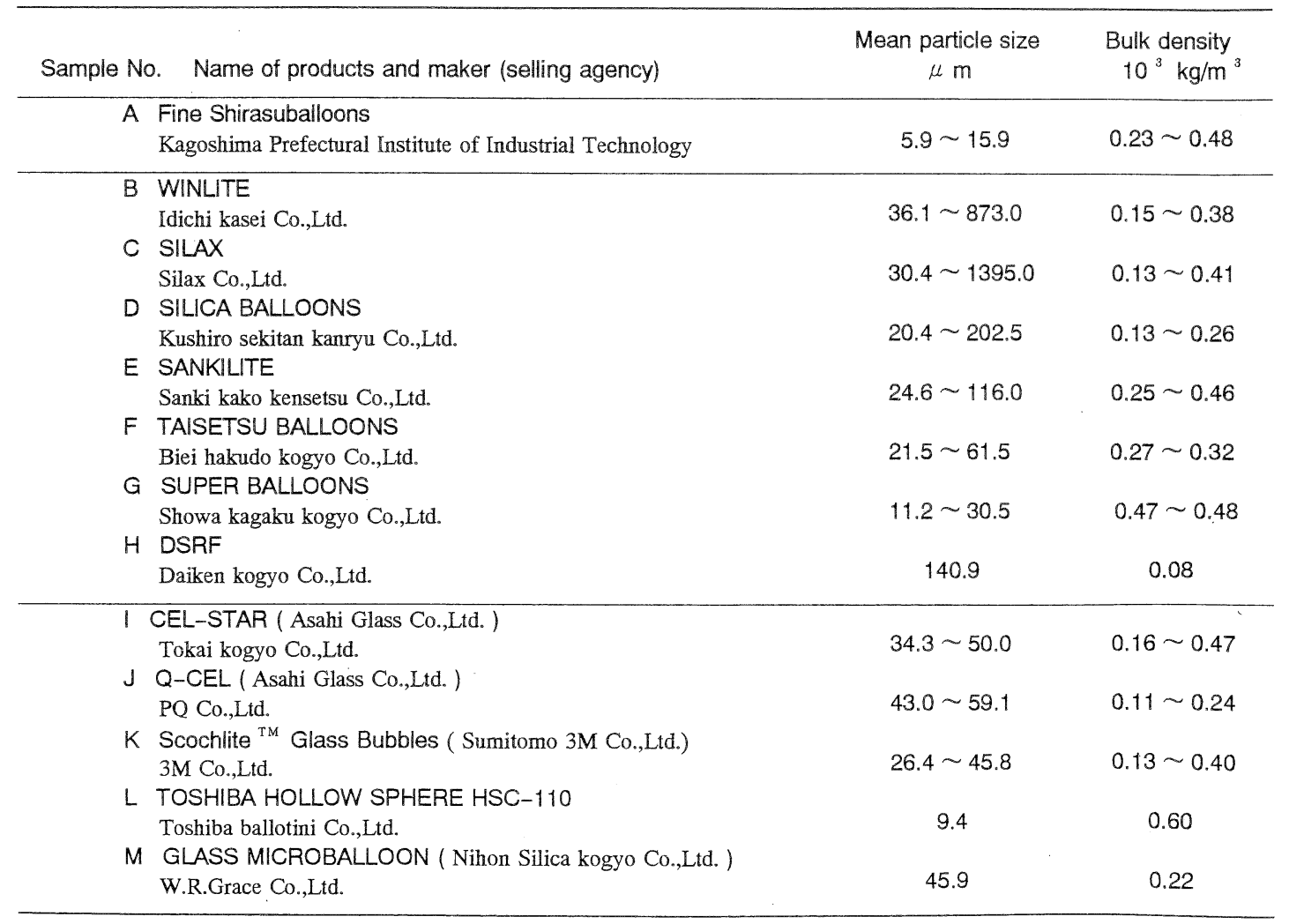


Table 2. Physical Properties of Fine Shirasuballoons, Conventional Shirasuballoons and conventional glass ballons

\begin{tabular}{|c|c|c|c|c|}
\hline Sample No & Name of products & $\begin{array}{l}\text { Mean particle size } \\
\qquad \mu \mathrm{m}\end{array}$ & $\begin{array}{l}\text { Bulk density } \\
10^{3} \mathrm{~kg} / \mathrm{m}^{3}\end{array}$ & $\begin{array}{l}\text { Particire density } \\
10^{3} \mathrm{~kg} / \mathrm{m}^{3}\end{array}$ \\
\hline 1 & FSb-Yoshida Shirasu & 15.9 & 0.27 & 1.32 \\
\hline 2 & FSb-Yoshida Shirasu & 15.1 & 0.30 & 1.24 \\
\hline 3 & FSb-Yoshida Shirasu & 10.6 & 0.34 & 1.52 \\
\hline 4 & FSb-Yoshida Shirasu & 13.8 & 0.36 & 1.17 \\
\hline 5 & FSb-Yoshida Shirasu & 11.5 & 0.39 & 1.36 \\
\hline 6 & FSb-Kakuto Shirasu & 13.3 & 0.48 & 1.67 \\
\hline 7 & FSb-Kakuto Shirasu & 13.0 & 0.47 & 1.59 \\
\hline 8 & FSb-Nakano Hakudo & 13.3 & 0.41 & 1.69 \\
\hline 9 & FSb-Nakano Hakudo & 15.3 & 0.48 & 1.90 \\
\hline 10 & FSb-Biei Hakudo & 8.8 & 0.39 & 1.54 \\
\hline 11 & FSb-Biei Hakudo & 7.4 & 0.39 & 1.51 \\
\hline 12 & SILAX PB-33 & 47.7 & 0.32 & 0.98 \\
\hline 13 & SANKILITE YO4 & 24.6 & 0.46 & 1.04 \\
\hline 14 & CEL-STAR Z-39 & 50.0 & 0.24 & 0.37 \\
\hline 15 & CEL-STAR PZ-6000 & 34.7 & 0.43 & 0.66 \\
\hline
\end{tabular}

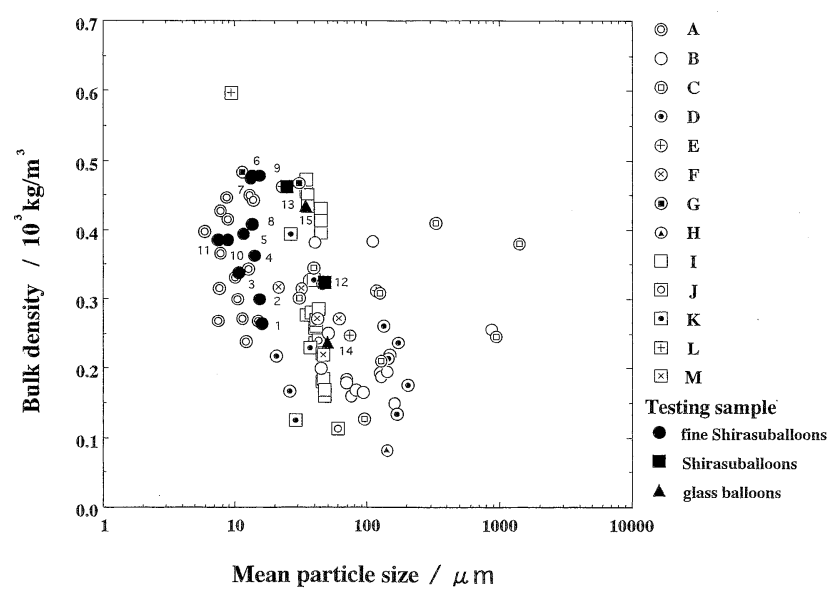

Fig. 1. Relationship between bulk densities and mean particle sizes of fine Shirasuballoons, conventional Shirasuballoons and conventional glass balloons, where closed marks indicate testing samples.

合成した微粒シラスバルーンは平均粒径5.9 15.9 $\mu \mathrm{m}$ ，かさ 密度 $0.23 \sim 0.48\left(10^{3} \mathrm{~kg} / \mathrm{m}^{3}\right)$ の範囲, 市販のシラスバルーン
は平均粒径11.2 1395.0 $\mu \mathrm{m}$, かさ密度 $0.08 \sim 0.48\left(10^{3} \mathrm{~kg} / \mathrm{m}^{3}\right)$ の範囲, 市販のガラスバルーンは平均粒径 $9.4 \sim 59.1 \mu \mathrm{m}$, かさ 密度0.11 0.60 $\left(10^{3} \mathrm{~kg} / \mathrm{m}^{3}\right)$ の範囲に分布している.シラス バルーンはガラスバルーンに比べて広い粒度範囲の製品が存在 している.

微粒シラスバルーンは, 原料のガラス質火山砕屑物の粉砕物 を急速加熱して発泡させて合成するが，その発泡源は，原料に 含まれる水分であり, この水含有量が発泡性と相関性がある9). かさ密度の分布は, 原料により水含有量が異なることや焼成温 度が大きく影響する ${ }^{8), 9)}$. シラスバルーンの広い粒度範囲は, ふるい分けした粒度の異なる原料を用いていることが大きな要 因であると考えられる。

表 2 の強度試験, 耐熱性試験, 耐化学薬品性試験に用いた 微粒シラスバルーンは, 吉田シラス, 加久藤シラス, 中野白 土, 美瑛白土から合成した. シラスバルーンはシラックスウ製 の SILAX PB-33，三機化工建設製のサンキライト YO4，ガ ラスバルーンは旭硝子製の CEL-STAR Z-39 と射出成形用の CEL-STAR PZ-6000を用いた。表 3 には，バルーンの主な組 成の例2),3)を示す。合成した微粒シラスバルーンの組成は, 基 本的にシラスバルーンと同等である. シラスバルーンは, アル ミナ成分を13〜14\%含有しているアルミノケイ酸塩ガラスか

Table 3. Chemical Compositions of Fine Shirasuballoons, Conventional Shirasuballoons and Conventional Glass Balloons

\begin{tabular}{lccc} 
& fine Shirasuballoons & Shirasuballoons & glass balloons \\
\hline $\mathrm{SiO}_{2}$ & $73 \sim 76$ & $70 \sim 77$ & $58 \sim 75$ \\
$\mathrm{Al}_{2} \mathrm{O}_{3}$ & $13 \sim 14$ & $13 \sim 14$ & $0 \sim 3$ \\
$\mathrm{~B}_{2} \mathrm{O}_{3}$ & - & - & $11 \sim 25$ \\
$\mathrm{~K}_{2} \mathrm{O}$ & $3.3 \sim 4.7$ & & $0 \sim 3$ \\
$\mathrm{Na}_{2} \mathrm{O}$ & $1.8 \sim 3.7$ & $6 \sim 7$ & $3 \sim 12.5$ \\
$\mathrm{CaO}$ & $1.1 \sim 1.7$ & & $5 \sim 15$ \\
$\mathrm{MgO}$ & $0.1 \sim 0.4$ & $2 \sim 3$ & $0 \sim 3$ \\
$\mathrm{Fe}_{2} \mathrm{O}_{3}$ & $1.6 \sim 1.8$ & - & - \\
$\mathrm{TiO}_{2}$ & $0.1 \sim 0.3$ & - & - \\
$\mathrm{ZnO}$ & - & - & $0 \sim 3$ \\
$\mathrm{P}_{2} \mathrm{O}_{5}$ & - & - & $0 \sim 3$ \\
$\mathrm{SO}_{3}$ & - & - & $0.05 \sim 1$ \\
$\mathrm{Ig}$. loss & $0.9 \sim 1.5$ & & - \\
\hline
\end{tabular}


らなる。

バルーンの用途として樹脂との複合を考慮した場合, 射出成 形又は押出し成形が可能である必要がある. 押出し成形機の場 合は数 MPa で押出し可能であるので10), バルーンの強度試験 としては, 静水圧 $10 \mathrm{MPa}$ で10 min 保持後の体積減少率を測 定した。体積減少率は次の式で算出した。

体積減少率 $(\%)=(1-($ 破壊前粒子密度/破壊後粒子密度 $))$

$$
\times 100
$$

強度試験としては, 微粒シラスバルーン2 11, シラスバ ルーン 12,13 , ガラスバルーン14, 15を用いた. 図 2 に乾式充 填法で加圧前後の微粒シラスバルーン 5 , シラスバルーン 12 , ガラスバルーン14の電子頙微鏡写真を示す。加圧後には, ガ
ラスバルーン住，破确し粉々になっているが，微粒シラスバ ルーンは，原形を多くとどめていることが分かる。

体積減少率と破壞前の平均粒径について静水圧法と乾式充填 法で行った結果を図 3 に示ず，加圧方法の違いで，体積減少率 に大きな差があり，乾式充填法の万が体積減少率が大きくなっ ている．これは，静水压法の等方加圧に対して，乾式充填法で は粒子同士の点接触部分の荷重集中と剪断力が大きく働いてい るためと考えられる。実用上の複合化においては，強い剪断力 が働く場合が多いので，乾式充填法での強度評価は，複合化の 目安になると考えられる。

体積減少率と破壞前の粒子密度について静水圧法上乾式充填 法で行った結果を図 4 に示す。 $10 \mathrm{MPa}$ 程度の静水圧法での体

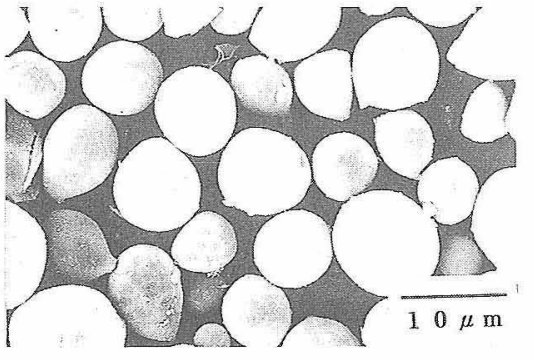

before pressurization

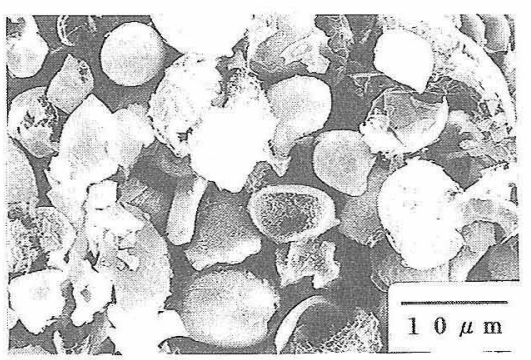

after pressurization

(a) fine Shirasuballoons

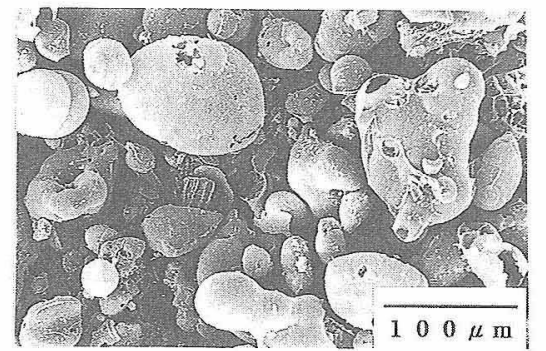

before pressurization

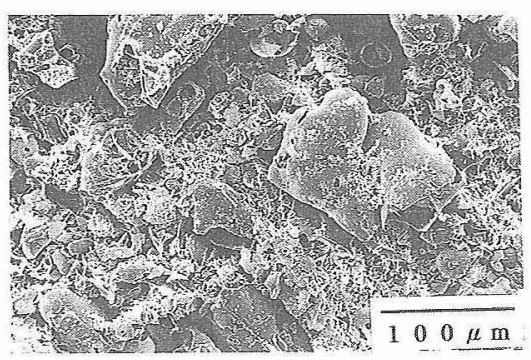

after pressurization

(b) Shirasuballoons

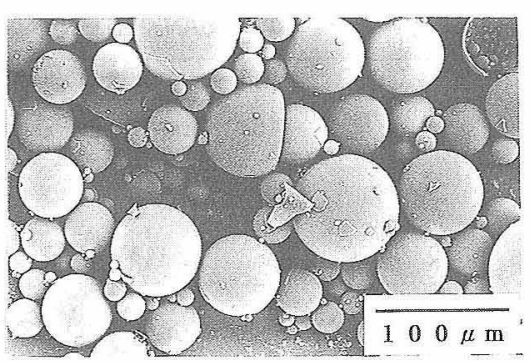

before pressurization

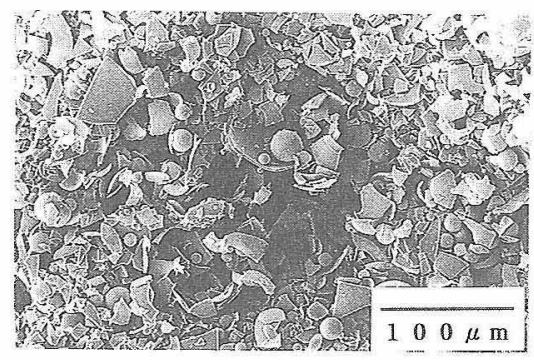

after pressurization

(c) glass balloons

Fig. 2. SEM micrographs of the hollow microspheres before and after pressuring at $10 \mathrm{MPa}$ for $10 \mathrm{~min}$; (a) fine Shirasuballoons, (b) conventional Shirasuballoons and (c) conventional glass balloons.

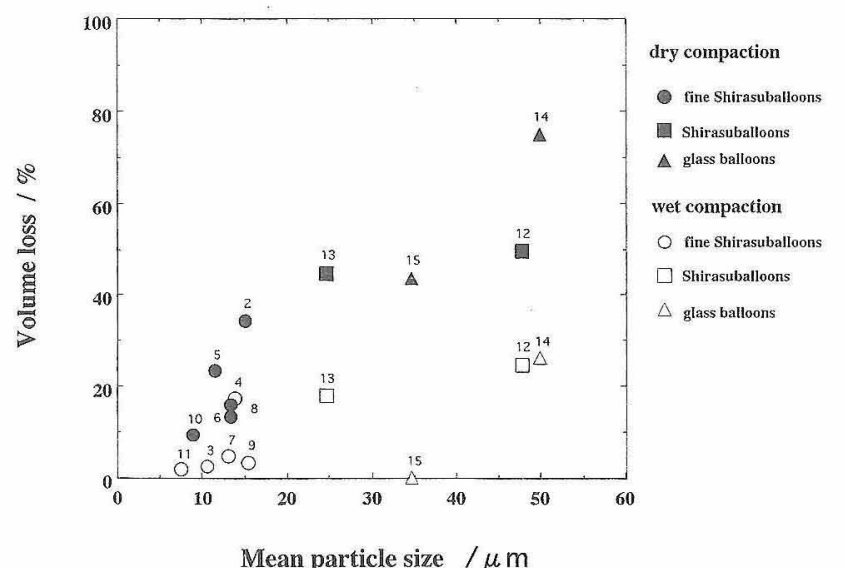

Fig. 3. Relationship between volume losses and mean particle sizes of fine Shirasuballoons, conventional Shirasuballoons and conventional glass balloons. Volume loss, which is a measure of the strength of the hollow microspheres, is determined by the following equation as (1-(particle density before testing/particle density after testing) $) \times 100$.

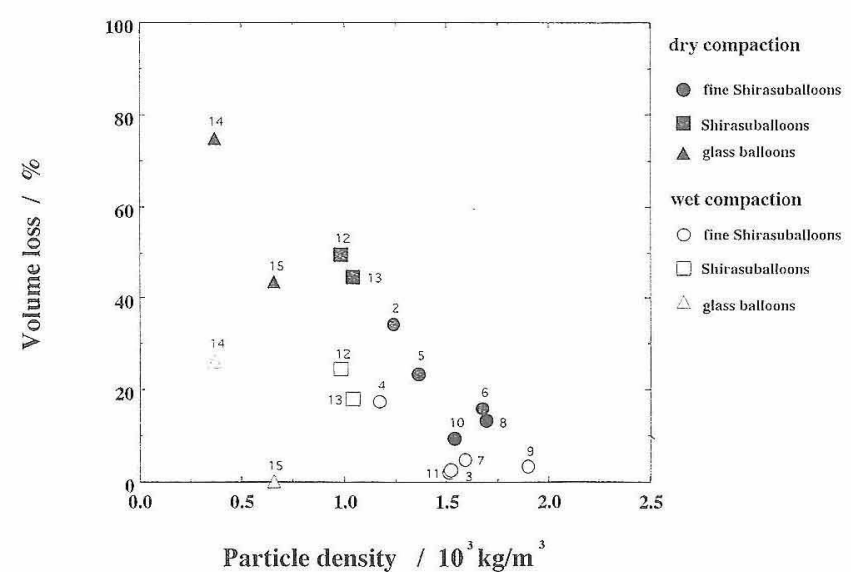

Fig. 4. Relationship between volume losses and particle densities of fine Shirasuballoons, conventional Shirasuballoons and conventional glass balloons. Volume loss, which is a measure of the strength of the hollow microspheres, is determined by the following equation as (1-(particle density before testing/particle density after testing) $) \times 100$. 
積減少率は粒子密度との相関性は低いが, 乾式充填法での体積 減少率は, 粒子密度上高い相関性が認められた。図 3 と比較 して, 乾式充填法での体積減少率は, 平均粒径よりも粒子密度 と高い相関性を示した。また，微粒シラスバルーンは，ほかの バルーンよりも体積減少率が小さく, その中でも粒子密度の大 きいものほど破壞され難い傾向を示した。したがって，平均粒 径 $20 \mu \mathrm{m}$ 以下の微粒シラスバルーンは, 粒子密度がほかのバ ルーンより大きいことから, 相対的に高強度を示すことが分 かった。

耐熱性試験には，微粒シラスバルーン 1 ，シラスバルーン 12，ガラスバルーン14を用いた．図 5 に，大気中で $2 \mathrm{~h}$ 加熱後 の白色度の変化を示した。バルーンは, 塗料, プラスチック， 化栍品など目に触れる製品に用いられる場合, より白色度の高 いものが適しており，熱による退色性もバルーンの品質の一 と考えら机る。微粒シラスバルーン及びシラスバルーンは

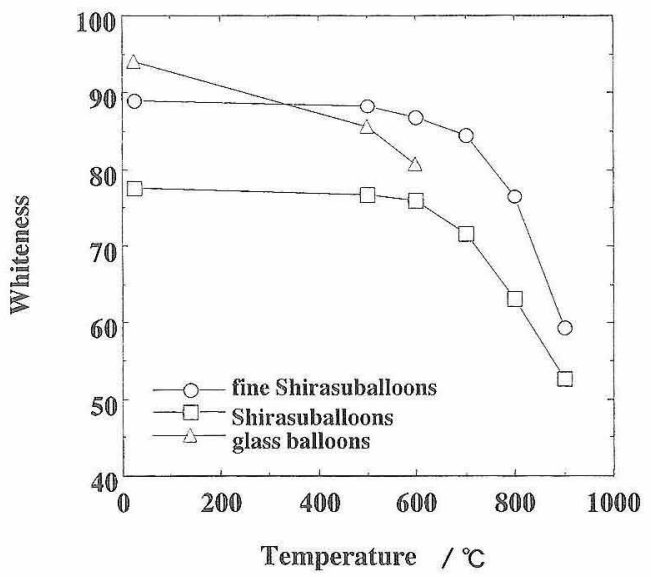

Fig. 5. Whitenesses of fine Shirasuballoons, conventional Shirasuballoons and conventional glass balloons after heating at fixed temperatures for $2 \mathrm{~h}$ in air. $600^{\circ} \mathrm{C}$ 以上で徐々に白色度が低下しているが，これは原料に含 なれる鉄分が酸化着色するためと考えら扎る13)。図 6 には， 所定の温度で大気中 $2 \mathrm{~h}$ 加熱後のかさ密度の变化を示す。微粒 シラスバルーン及びシラスバルーント $900^{\circ} \mathrm{CKお゙いて，ガラス}$ バルーンは $700^{\circ} \mathrm{C} に$ 抢いてかさ密度が急激に増加している。 図 7 Kは, $800^{\circ} \mathrm{C}, 900^{\circ} \mathrm{C}$ 加熱後の微粒シラスバルーン, シラス バルーン及び $700^{\circ} \mathrm{C}, 800^{\circ} \mathrm{C}$ 加熱後のガラスバルーンの電子顕微 鏡写真を示す，ガラスバルーンは， $800^{\circ} \mathrm{C}$ で融着によるバルー ン形態の変化が観察されるが，微粒シラスバルーン及びシラス

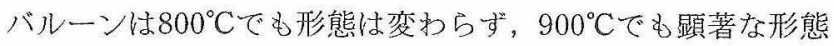
の変化は認められない。しかし，前述したようにかさ密度は $900^{\circ} \mathrm{C}$ で急激に増加している。これらの結果は，かさ密度の変 化が耐熱性の有効な指標になることを示している。加熱による かさ密度の変化から微粒シラスバルーン及びシラスバルーン は，ガラスバルーンに比べて $200^{\circ} \mathrm{Cほど}$ 耐熱性が高いという

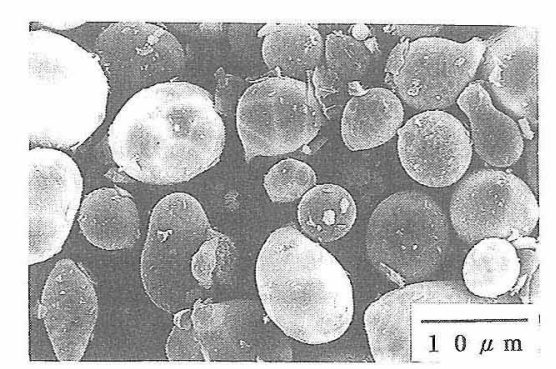

at $800{ }^{\circ} \mathrm{C}$

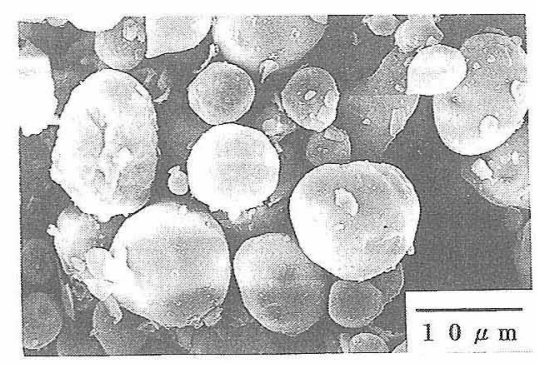

at $900{ }^{\circ} \mathrm{C}$

(a) fine Shirasuballoons

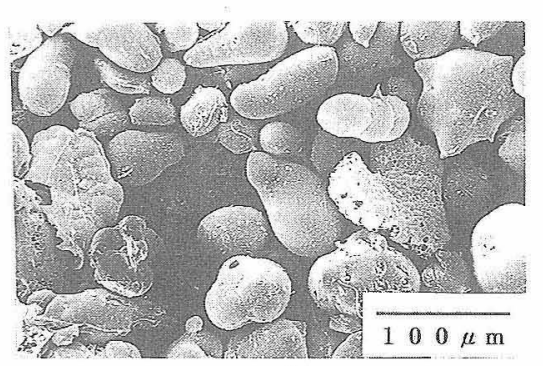

at $800{ }^{\circ} \mathrm{C}$

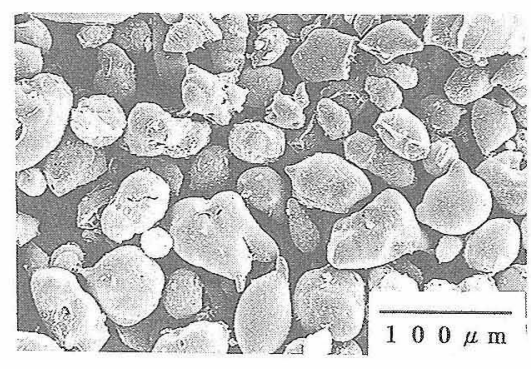

at $900{ }^{\circ} \mathrm{C}$

(b) Shirasuballoons

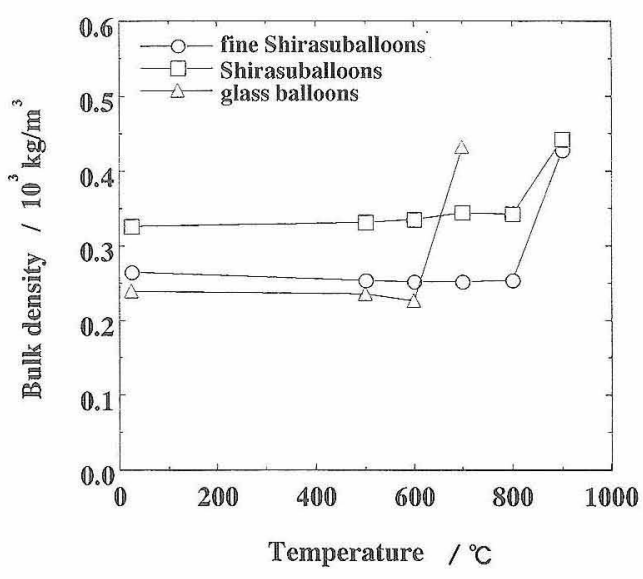

Fig. 6. Bulk densities of fine Shirasuballoons, conventional Shirasuballoons and conventional glass balloons after heating at fixed temperatures for $2 \mathrm{~h}$ in air.

Fig. 7. SEM micrographs after heating at fixed temperatures for $2 \mathrm{~h}$ in air; (a) fine Shirasuballoons, (b) conventional Shirasuballoons and (c) conventional glass balloons. 


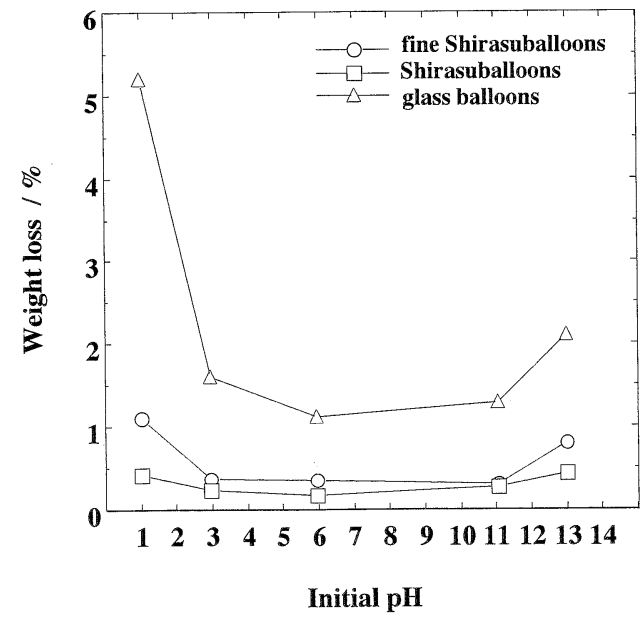

Fig. 8. Relationship between weight losses and initial $\mathrm{pH}$ of fine Shirasuballoons, conventional Shirasuballoons and conventional glass balloons.

\section{ことができる。}

耐化学薬品性には, 微粒シラスバルーン 1 , シラスバルーン 12, ガラスバルーン 14 を用いた。図 8 に，その重量減少率と 浸せき前の $\mathrm{pH}$ を示す。測定したガラスバルーンは，ホウ酸や 溶解成分を多く含むため耐酸, 耐アルカリ性に劣っており, $\mathrm{pH} 1$ で $5 \%$ 以上の重量減少を示した，微粒シラスバルーン及 びシラスバルーンは，アルミナ成分を含むアルミノケイ酸塩ガ ラスからなるので, 重量減少率が $1.1 \%$ 以下であり, ガラスバ ルーンより耐化学薬品性に優れている. 浸せき後の $\mathrm{pH}$ の変化 を測定した結果, ガラスバルーン, 微粒シラスバルーン, シラ スバルーンの順で, $\mathrm{pH}$ の変化量が大きくなっており, 重量減 少率上同じ傾向を示した。微粒シラスバルーンがシラスバルー ンより，わずかに重量減少率が大きいのは，微粒シラスバルー ンの比表面積 $\left(7700 \mathrm{~m}^{2} / \mathrm{kg}\right.$ ) がシラスバルーンの比表面積 $\left(3700 \mathrm{~m}^{2} / \mathrm{kg}\right)$ より大きいためであると考えられる。

\section{4. 結 論}

微粒シラスバルーン，市販のシラスバルーン及び市販のガラ スバルーンについて, 強度, 耐熱性, 耐化学薬品性の検討を行 い, 以下の結果を得た.
(1) 微粒シラスバルーン，シラスバルーン及びガラスバ ルーンの強度は, 平均粒径よりも粒子密度と相関性が高い。

(2) 微粒シラスバルーンは, シラスバルーンやガラスバ ルーンに比べて, 粒子密度が大きく, 相対的に高強度を示し た。

（3）微粒シラスバルーン及びシラスバルーンは，大気中で の耐熱性試験の結果, $800^{\circ} \mathrm{C}$ をで室温と同程度の軽さを保持し て抢り，ガラスバルーンに比べて約 $200^{\circ} \mathrm{C}$ 耐熱性が高いことが 分かった。

(4) 微粒シラスバルーン及びシラスバルーンは, pH 1 $\mathrm{pH} 13$ の水溶液での $48 \mathrm{~h}$ 浸漬実験において, 重量減少率が $1.1 \%$ 以下であり, ガラスバルーンより耐化学薬品性に優れて いた.

謝辞 本研究を遂行するに当たり，(株)シラックスウの関 博光氏には, 有益なご指導, ご助言を頂いた。微粒シラスバルー ン原料は, 清新産業(株), 柏原産業, 丸中白土(株), 美瑛白土工 業(株)に提供して頂きました。大建工業(株)にはシラスバルーン を提供して頂きました。ここに，心から感謝の意を表します。

\section{文献}

1) 相馬 勲, 工業材料, 42, 102-11 (1994).

2）フィラー研究会編，“機能性フィラーの最新技術”, シーエム シー (1990) pp. 218-29.

3）フィラー研究会編，“フィラー活用事典”, 大成社（1994） pp. $163-65$.

4） 木村邦夫，陣内和彦，諫山幸夫，窯協，80，84-91（1972）。

5）(財) 日本産業技術振興協会編, シラスバルーンの市場動向調 查報告書, (財) 日本産業技術振興協会（1994）pp. 3-52。 に その後の調查を追加。

6) 西元研了, プラスチック成形加工学会第 3 回秋季大会成形加 エシンポジア’95講演要旨集 (1995) pp.157-60.

7）木村邦夫，陣内和彦，立山 博，セラミックス論文誌，99, 1240-44 (1991).

8）袖山研一，目 義雄，神野好孝，関 博光，粉体粉末冶金協 会誌, 42, 1128-35 (1995).

9）袖山研一, 目 義雄, 神野好孝, 田畑一郎, J.Ceram. Soc. Japan, 104, 963-68 (1996).

10）材料技術研究協会編，“複合材料と界面”，総合技術出版 (1986) pp. 186-96

11）VSI 研究会編, “新時代を築く火山噴出物”, リアライズ社 (1995) pp. 270-75.

12）日本セラミックス協会編，“セラミック工学ハンドブック”, 技報堂出版 (1989) pp. 1418 .

13）袖山研一，目 義雄，神野好孝，未発表データ。 